\title{
Studies on mosquitoes (Diptera: Culicidae) and anthropic environment. 4 - Survey of resting adults and synanthropic behaviour in South-Eastern, Brazil ${ }^{*}$
}

\author{
Oswaldo Paulo Forattini**, Iná Kakitani"*, Eduardo Massad"**, Daniel Marucci**
}

FORATTINI, O.P. et al. Studies on mosquitoes (Diptera: Culicidae) and anthropic environment. 4Survey of resting adults and synanthropic behaviour in SouthEastern, Brazil. Rev. Saúde Pública, 27: 398-411, 1993. Resting adults Culicidae were collected from January 1992 through January 1993 in several habitats of the Ribeira Valley region. The diversity of species found among them suggested that the vegetation remaining within human settlements favored the survival and the population increase of some mosquitoes. Among there are: Ae. scapularis, Ae. serratus, $C x$. (Culex), $C x$. nigripalpus and $C x$. (Melanoconion) such as $C x$. ribeirensis. That preservation role may be attributed to the rearing of livestock and the consequent increase in the number of blood sources. These species may be classified as hemisynanthropes and $C x$. oedipus apparently evolving to the eusynanthropic status. On the other hand, An. cruzii showed an asynanthropic behaviour, with a low degree of survival in the modified hum an environment. Epidemiological implications of the data are mentioned.

Keywords: Mosquitocs. Ecology, vectors.

\section{Inlroduction}

Outdoor sampling of resting adult Culicidae are usually madc to obtain females for blood meal analysis and parity rate determination. Searching for natural outdoor resting places is frequently difficult because mosquito populations are normally widely dispersed even when, as happens in some cases, specialized shelters are found. Nevertheless this is considered to be a biased procedure because it may not provide representative samples of the population (Service ${ }^{24,25} 1977,1993$ ). Thus, systematic evaluation of natural adult resting places is still needed for many mosquito species, especially in the Neotropical region. The great majority of studies so far carricd out have focused on malaria transmission, and we have concentrated on anophelines. Mosquito groups, in which some degree of synanthropy exists, were also studied. A problem is that available clata are largely observational (Brecland ${ }^{1,2}, 1972$;

\footnotetext{
* Supported by "Fundação de Amparo à Pesquisa do Estado de São Paulo (FAPESP)" (Grant n 90/33716).

** Department of Epidemiology, School of Public Ilealth, University of S. Paulo. Taxonomic and Systematic Research in Medical Entmolegy Unit of the University of S. Paulo/(NUPTEM) - S. Paulo, SP - Brazil

*** Department of Pathology, School of Medicine, University of S. Paulo, SP - Brazil
}

Reprints: O.P.Forattini - Av. Dr. Amaldo, 715 - 01246904 S. Paulo, SP - Brazil

Ediçĩo subvencionada pela F $\Lambda$ PESP. Processo Medicina 93/ 02085
Navarro et al. ${ }^{16,17}, 1986,1987$; Gomes and Forattini ${ }^{11}, 1990$; Natal et al. ${ }^{15}$, 1991; RubioPalis and Curtis $^{23}$, 1992). More recent researches, largely focusing on the culicids as a whole, have been carried out elsewhere (Reisen et al.22, 1982; Irby and Apperson ${ }^{13}$, 1992). In the Ribeira Valley region some of these studies have already been undertaken, mainly from the point of view of adult feeding preferences, resting places and dispersal patterns (Forattini et al 4,5,6, 1987, 1990).

Generally speaking, the larger part of the available data are related to artificial shelters sampling for the post appetential flight of female mosquitocs. Up to now few attempts have been made to study the resting places of male adults. Generally, species are more easily and reliably recognized, through their male characters (as also is their taxonomic identification) and the collection of males provides the opportunity to improve biodiversity studies. Following the researches programme on mosquitoes and anthropic environment, this paper presents the results obtained from collecting resting adults, paying particular attention to male.

\section{Study area}

Resting mosquitocs were collected in threc areas consisting of the Experimental Station (ES), Fonte (FT) and Pariquera Mirim (PQM) district. Detailed descriptions of these study sites have been presentcd clscwhere (Forattini ct al. $5,8,9,1987,1993$ ). From the environmental and landscape points of view, they are representative of the following: 


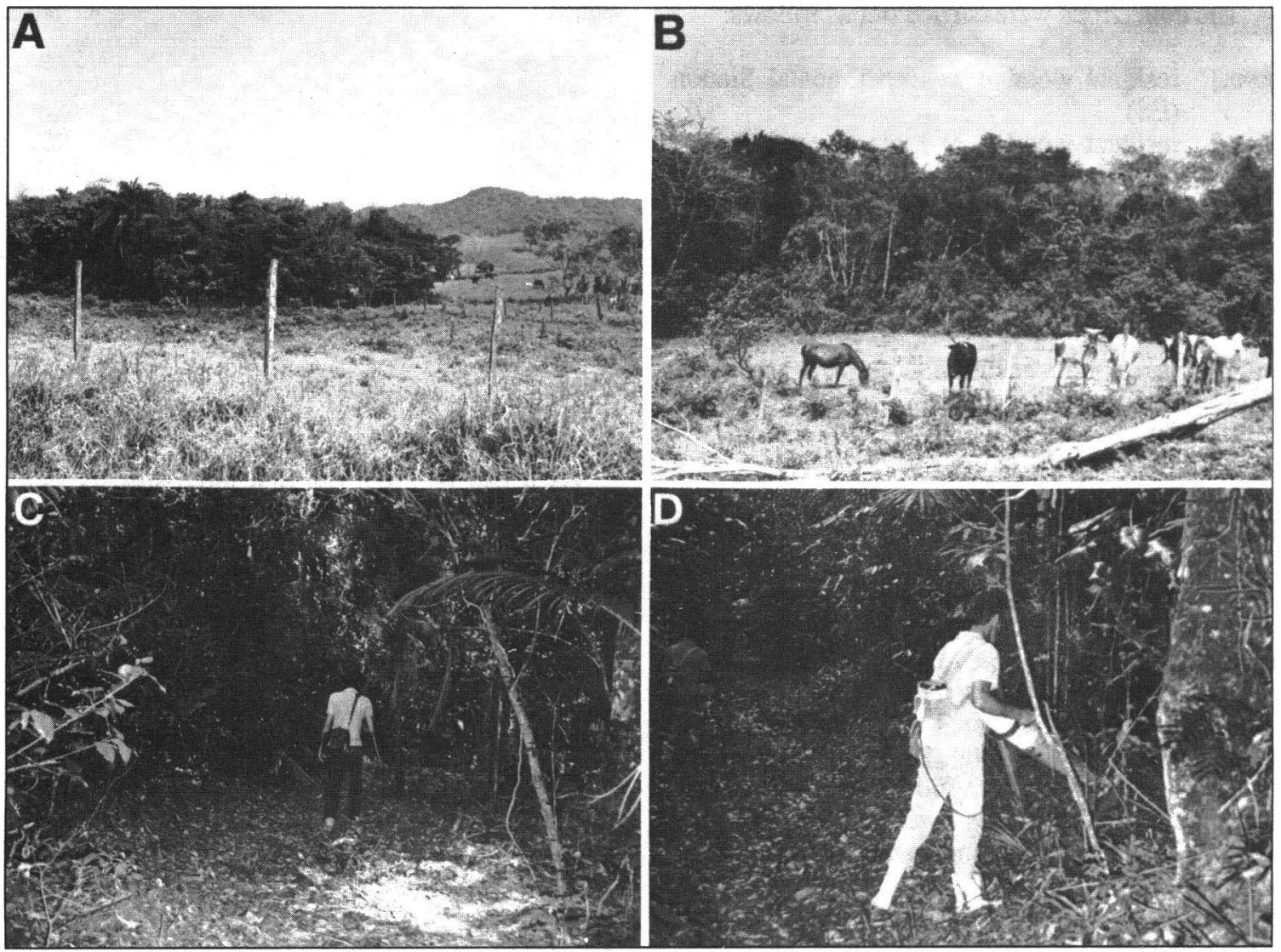

Figure 1. APariquera Mirim site view, with a secondary bush; B, C - Outside and inside aspects of the secondary bush; D - Sampling with the batterypowered aspirator.

a) ES is a large rural human settlement with a great degree of anthropic modifications, which includes the residual woods (RW) representing remnants of the original rain forest.

b) FT represents the wild regional environment characteristic of the original Atlantic rain forest ecosystem.

c) $P Q M$ represents a group of small rural human settlements with secondary growth of bushes that succeded the primitive covering of vegetation. These small sized and low height woods are characterized by the predominance of short slender trees and undergrowth (Figure $1, A, B$ and $C$ ).

\section{Material and Method}

Resting mosquitocs were collected from vegetation that could be classified as the natural shelters for adults, inside the wooded environment and at the ecotone between this and the open land, with graminous plants and shrubs up to 1.0 meter high. Sampling was diurnal and fortnightly, through out one year (January 1992 - January 1993). Each collection lasted one hour when, in general, five to ten 5minute collections were made. All the habitats were sequentially visited during each sampling occasion. Samples were collected using a batterypowered aspirator as described by $\mathrm{Nasci}^{14}$ (1981) (Figure 1,D). In order to provide comparisons, artificial resting places were sampled too. They were represented by the peridomestic environment at the Fonte (FT) houseliold, which has already been described in a previous paper (Forattini et al ${ }^{8}$. 1993).

After each collection the specimens were identificd and counted. Pcarson's correlation analysis was performed to identify any relationship between monthly dominance and rainfall levels. Biodiversity was calculated as proposed by Fisher et al. ${ }^{3}$ (1943). As for domiciliation, the Povolny ${ }^{19}$ (1971) classification concepts and the Nuorteva ${ }^{18}$ (1963) synanthropic index (b) were collected, as wcll as the synanthropic ratio (sr). Data on macroclimatic conditions were obtained from monthly records for the 19561985 period (Instituto Oceanográfico da USP'2, 1989). 
The collections were carried out as follows:

Asp.1 residual wood A at Experimental Station (ES).

Asp.2 residual wood B at Experimental Station (ES).

Asp.3 secondary bush at the Pariquera Mirim (PQM).

Asp.4 peridomiciliary dwellings at the Fonte (FT).

Asp.5 primitive rain forest at the Fonte (FT).

The taxonomic identifications are presented with the generic and subgencric names abbreviated according to Reinert ${ }^{20,21}(1975,1982)$.

\section{Results}

A total of 22,140 adult mosquitoes $(12,790 \mathrm{fe}$ males and 9,350 males) were collected, and these include 11,805 (53.3\%) from the ES; 5,563 (25.1\%) from PQM and 4,772 (21.6\%) from FT. The identifications obtained are presented in Tables 1 and 2 . Of that total, $77.2 \%$ (60.5\% of the females and practically $100.0 \%$ of the males) were identified to species level and $39.5 \%$ as belonging to various taxonomic groups, or as yet unknown taxa.

Residual woods (ES) - Of the total specimens collected there, $75.3 \%$ were identified as specics and the pattem of the most prevalent was as follows (Asp.1 and Asp.2):

Species

Aodes serratus

Culex nigripalpus

Aedes scapularis

Cx. declarator

Cx. mollis

Cx. lygrus

Cx. ribeirensis

Cx. pedroi

Total

The monthly percentage distributions of the total number of each of the three most prevalent species are presented in Figure $2 \mathrm{~A}, \mathrm{~B}, \mathrm{C}$. In February a marked decrease was obscrved for all of these mosquitocs. The particularly dry weather that occurred during that period could, at least to some cxtent, explain this. Despite the proximity of the irrigation system at ES, the species An. albitarsis was virtually absent.

Secondary bush (PQM) - Aller the collections, $79.6 \%$ of the specimens caught were identified to species, and the most prevalent were classified as follows (Asp.3):
Species

$\%$

Aedes serratus

Culex nigripalpus

24.8

Ae. scapularis

17.8

Ae. nubilus

Cx. declarator

Cx. mollis

Psorophora lutzii

Cx. lygrus

Cx. sacchettae

$C x$. ribeirensis

Cx. pedroi

9.0

8.9

4.2

4.2

3.6

3.0

1.5

1.1

0.9

Total

79.0

As it can be seen, the first three species were the same as those found in the ES residual woods. In addition, Ae. nubilus was significantly present in this secondary bush habitat. The monthly percentage distributions are presented in the Figure 2 A,B,C,D.

Peridomestic environment (FT)- Of the resting specimens collected in this habitat, $93.0 \%$ were identified to species, the most prevalent being the following (Asp.4):

Species

$\%$

Culex quinquefasciatus

86.0

$C x$ oedipus

Total

95.9

As expected, Culex quinquefasciatus was predominant. In addition, $C x$. oedipus figures as a significant mosquito found in this environment and therefore deserves of attention. The monthly percentage of regarding these two species is presented in Figure 3A.

Primitive forest (FT) $-71.4 \%$ of the specimens collected there were identified to species, among them the most predominant were as follows (Asp.5):

Species $\%$

Anopheles cruzii

Culex neglectus

15.9

Aedes serratus

Ae. hortator (near)

12.3

Psorophora ferox

11.8

Ae. scapularis

5.4

Cx. imitator

$C x$. nigripalpus

$C x$. aphylactus

4.9

Cx. galvaoi

4.9

3.6

2.8

Total

80.1 
Forattini, O.P. et al.

Rev. Saúde Pública, 27(6), 1993

Table 1. Resting adults Culicidae collected at the Experimental Station (ES) and Pariquera Mirim (PGM) district, from January 1992 through January 1993.

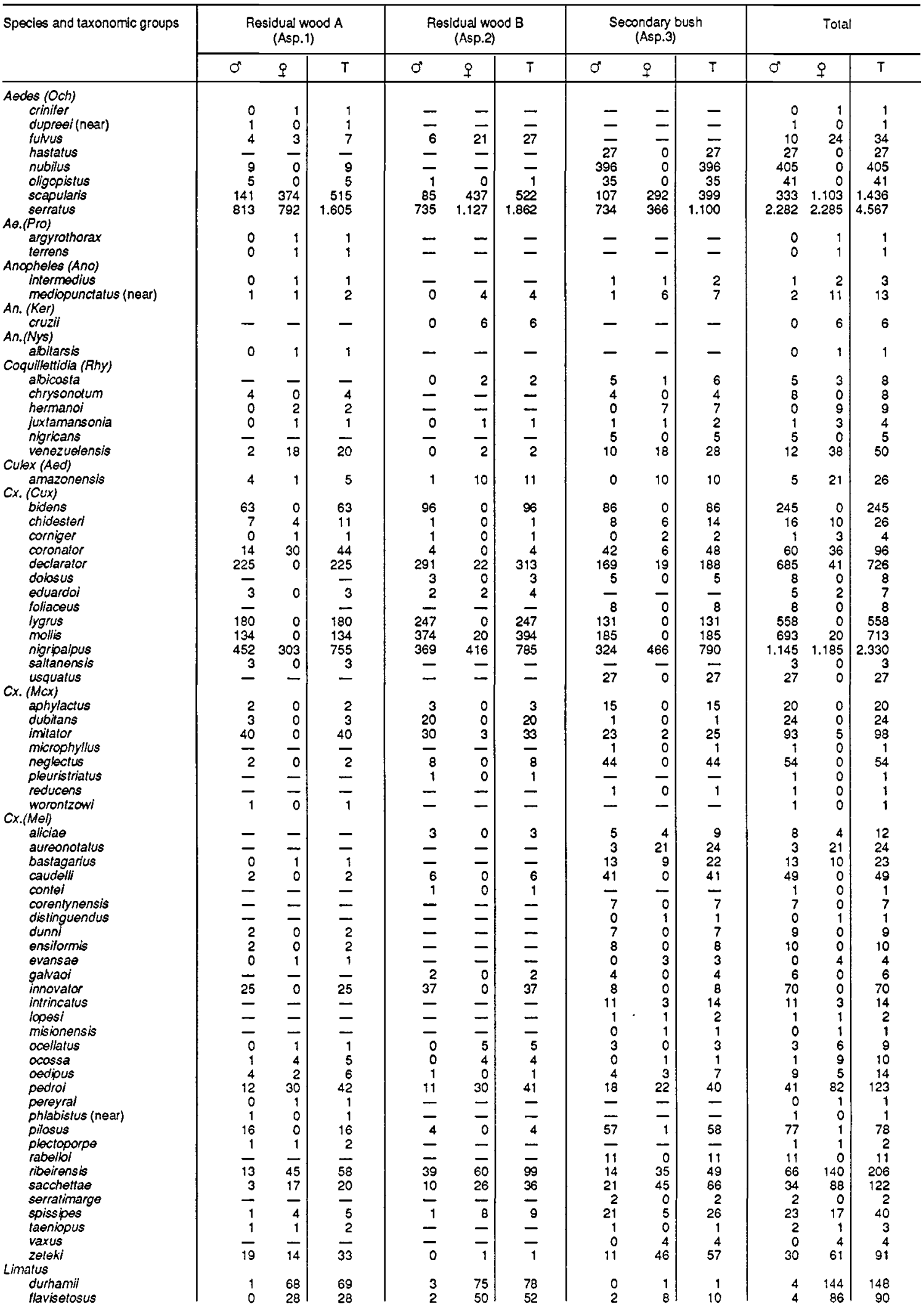




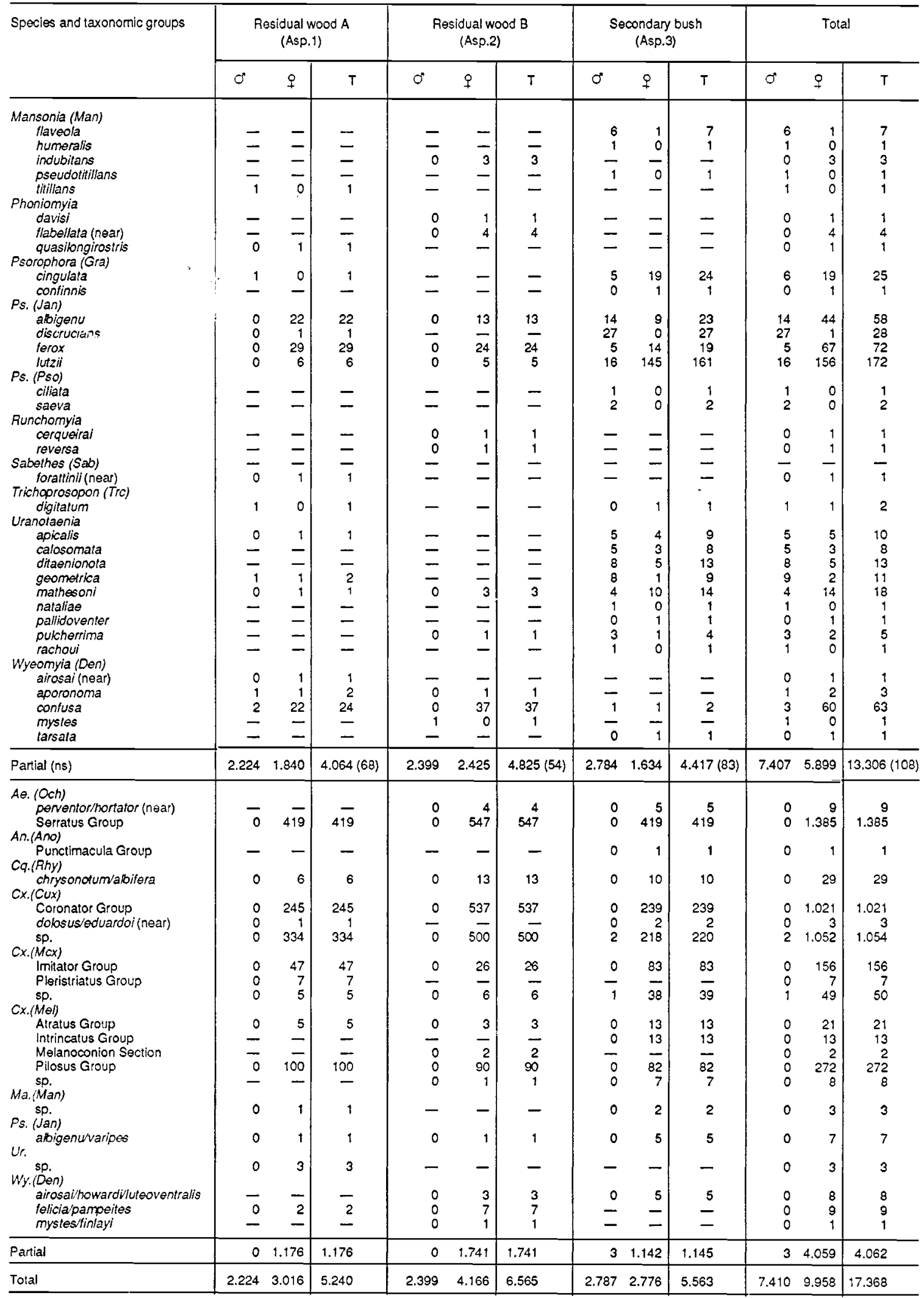

(ns) - Number of species. 
Table 2. Resting adults Culicidae collected at the Fonte (FT) region from January 1992 through January 1993.

\begin{tabular}{|c|c|c|c|c|c|c|c|c|c|}
\hline \multirow[t]{2}{*}{ Species and taxonomic groups } & \multicolumn{3}{|c|}{$\begin{array}{c}\text { Household (peridomestic) } \\
\text { (Asp.4) }\end{array}$} & \multicolumn{3}{|c|}{$\begin{array}{l}\text { Primitive forest } \\
\text { (Asp.5) }\end{array}$} & \multicolumn{3}{|c|}{ Total } \\
\hline & $\sigma$ & 오 & $T$ & $0^{\prime}$ & 9 & $\mathrm{~T}$ & $0^{\prime}$ & $q$ & $T$ \\
\hline $\begin{array}{l}\text { Aedes (How) } \\
\text { fulvithorax }\end{array}$ & - & - & - & 2 & 0 & 2 & 2 & 0 & 2 \\
\hline $\begin{array}{l}\text { Ae.(Och) } \\
\text { fluviatilis }\end{array}$ & 0 & 1 & 1 & - & - & - & 0 & 1 & 1 \\
\hline hastatus & - & - & - & 2 & 0 & 2 & 2 & 0 & 2 \\
\hline hortator (near) & - & - & - & $5 \overline{1}$ & 206 & $25 \overline{7}$ & $5 \overline{1}$ & 206 & 257 \\
\hline nubilus & 1 & 0 & 1 & 2 & 0 & 2 & 3 & 0 & 3 \\
\hline oligopistus & - & - & - & 39 & 0 & 39 & 39 & 0 & 39 \\
\hline scapularis & 0 & 13 & 13 & 20 & 87 & 107 & 20 & 100 & 120 \\
\hline $\begin{array}{l}\text { serratus } \\
\text { Ae.(Pro) }\end{array}$ & 1 & 0 & 1 & 95 & 174 & 269 & 96 & 174 & 270 \\
\hline $\begin{array}{c}\text { argyrothorax } \\
\text { Anopheles (Ano) }\end{array}$ & - & - & - & 0 & 5 & 5 & 0 & 5 & 5 \\
\hline eiseni & - & - & - & 1 & 0 & 1 & 1 & 0 & 1 \\
\hline $\begin{array}{l}\text { intermedius } \\
\text { An. (Ker) }\end{array}$ & - & - & - & 1 & 1 & 2 & 1 & 1 & 2 \\
\hline bellator & 0 & 1 & 1 & 0 & 11 & 11 & 0 & 12 & 12 \\
\hline $\begin{array}{l}\text { cruzii } \\
\text { An.(Ste) }\end{array}$ & 0 & 5 & 5 & 0 & 349 & 349 & 0 & 354 & 354 \\
\hline $\begin{array}{c}\text { kompi } \\
\text { Culex (Aed) }\end{array}$ & - & - & - & 3 & 0 & 3 & 3 & 0 & 3 \\
\hline $\begin{array}{l}\text { amazonensis } \\
\text { Cx.(Car) }\end{array}$ & - & - & - & 4 & 0 & 4 & 4 & 0 & 4 \\
\hline urichii & - & - & - & 1 & 0 & 1 & 1 & 0 & 1 \\
\hline $\begin{array}{c}\text { Cx. (Cux) } \\
\text { bidens }\end{array}$ & 3 & 0 & 3 & 4 & 0 & 4 & 7 & 0 & 7 \\
\hline chidesteri & 1 & 1 & 2 & - & - & - & $i$ & 1 & 2 \\
\hline corniger & 2 & 4 & 6 & - & - & - & 2 & 4 & 6 \\
\hline coronator & - & - & - & 8 & 0 & 8 & 8 & 0 & 8 \\
\hline declarator & - & - & - & 19 & 0 & 19 & 19 & 0 & 19 \\
\hline lygrus & - & - & - & 9 & 0 & 9 & 9 & 0 & 9 \\
\hline mollis & 2 & 0 & 2 & 44 & 0 & 44 & 46 & 0 & 46 \\
\hline nigripalpus & 3 & 5 & 8 & 27 & 51 & 78 & 30 & 56 & 86 \\
\hline quinquefasciatus & 887 & 482 & 1.369 & - & - & - & 887 & 482 & 1.369 \\
\hline usquatus & 4 & 0 & 4 & 22 & 0 & 22 & 26 & 0 & 26 \\
\hline $\begin{array}{l}C \times .(M c x) \\
\text { aphylactus }\end{array}$ & - & - & - & & & & & & \\
\hline $\begin{array}{l}\text { aphylactus } \\
\text { dubitans }\end{array}$ & - & - & - & $\begin{array}{r}62 \\
3\end{array}$ & $\begin{array}{l}0 \\
0\end{array}$ & $\begin{array}{r}62 \\
3\end{array}$ & $\begin{array}{r}62 \\
3\end{array}$ & 0 & $\begin{array}{r}62 \\
3\end{array}$ \\
\hline imitator & 2 & 1 & 3 & 101 & 5 & 106 & 103 & 6 & 109 \\
\hline inimitabilis & - & - & - & 1 & 0 & 1 & 1 & 0 & 1 \\
\hline neglectus & 5 & 0 & 5 & 347 & 0 & 347 & 352 & 0 & 352 \\
\hline reducens & - & - & - & 4 & 2 & 6 & 4 & 2 & 6 \\
\hline $\mathrm{CX}_{\mathrm{X}}(\mathrm{Mel})$ & & & & & & & & & \\
\hline aliciae & 5 & 0 & 5 & 2 & 0 & 2 & 7 & 0 & 7 \\
\hline bastagarius & 0 & 4 & 4 & - & - & - & 0 & 4 & 4 \\
\hline contei & 1 & 0 & 1 & - & - & - & 1 & 0 & 1 \\
\hline distinguendus & 1 & 0 & 1 & 2 & 2 & 4 & 3 & 2 & 5 \\
\hline dunni & 2 & 0 & 2 & 3 & 0 & 3 & 5 & 0 & 5 \\
\hline galvaoi & - & - & - & 55 & 0 & 55 & 55 & 0 & 55 \\
\hline innovator & 2 & 0 & 2 & - & - & - & 2 & 0 & 2 \\
\hline intrincatus & - & - & - & 2 & 0 & 2 & 2 & 0 & 2 \\
\hline misionensis & - & - & - & 1 & 1 & 2 & 1 & 1 & 2 \\
\hline ocellatus & - & - & - & 13 & 14 & 27 & 13 & 14 & 27 \\
\hline oedipus & 23 & 87 & 110 & - & - & - & 23 & 87 & 110 \\
\hline pedroi & 1 & 1 & 2 & 2 & 7 & 9 & 3 & 8 & 11 \\
\hline pilosus & 1 & 0 & 1 & 7 & 0 & 7 & 8 & 0 & 8 \\
\hline plectoporpe & 2 & 2 & 4 & - & - & - & 2 & 2 & 4 \\
\hline rabelloi & 1 & 0 & 1 & - & - & - & 1 & 0 & 1 \\
\hline ribeirensis & $i$ & 0 & 1 & 0 & 2 & 2 & 1 & 2 & 3 \\
\hline sacchettae & - & - & - & 1 & 1 & 2 & 1 & 1 & 2 \\
\hline vaxus & 5 & 7 & 12 & 0 & 1 & 1 & 5 & 8 & 13 \\
\hline zeteki & - & - & - & 6 & 23 & 29 & 6 & 23 & 29 \\
\hline Limatus .. & & & & & & & & & \\
\hline durhamii & 0 & 1 & 1 & 0 & 3 & 3 & 0 & 4 & 4 \\
\hline flavisetosus & 1 & 0 & 1 & 0 & 5 & 5 & 1 & 5 & 6 \\
\hline
\end{tabular}




\begin{tabular}{|c|c|c|c|c|c|c|c|c|c|}
\hline \multirow[t]{2}{*}{ Species and taxonomic groups } & \multicolumn{3}{|c|}{$\begin{array}{l}\text { Household (peridomestic) } \\
\text { (Asp.4) }\end{array}$} & \multicolumn{3}{|c|}{$\begin{array}{l}\text { Primitive forest } \\
\text { (Asp.5) }\end{array}$} & \multicolumn{3}{|c|}{ Total } \\
\hline & $\sigma^{x}$ & $q$ & $T$ & $\sigma$ & $q$ & $T$ & O & $q$ & $T$ \\
\hline $\begin{array}{l}\text { Phoniomyia } \\
\text { davisi } \\
\text { flabellata } \\
\text { longirostris } \\
\text { pallidoventer } \\
\text { quasilongirostris } \\
\text { theobaldi } \\
\text { Psorophora (Gra) } \\
\text { cingulata } \\
\text { Ps. (Jan) } \\
\text { albigenu } \\
\text { ferox } \\
\text { lutzii } \\
\text { Runchomyia } \\
\text { humboldti } \\
\text { reversa } \\
\text { roversa (near) } \\
\text { Sabethes (Sbn) } \\
\text { undosusffabricii } \\
\text { Shannoniana } \\
\text { fluviatilis } \\
\text { Uranotaenia } \\
\text { calosomata } \\
\text { lowii } \\
\text { mathesoni } \\
\text { pulcherrima } \\
\text { Wyeomyia (Den) } \\
\text { aporonoma } \\
\text { bourrouli } \\
\text { clasoleuca } \\
\text { confusa } \\
\text { felicialpampeites (near) } \\
\text { finlayi } \\
\text { shannoni }\end{array}$ & $\begin{array}{l}- \\
- \\
- \\
- \\
0 \\
0 \\
0 \\
1\end{array}$ & $\begin{array}{l}1 \\
2 \\
- \\
- \\
- \\
2\end{array}$ & $\begin{array}{l}1 \\
2 \\
3 \\
1 \\
1 \\
1 \\
\frac{1}{2} \\
1 \\
- \\
-\end{array}$ & $\begin{array}{l}1 \\
0 \\
0 \\
0 \\
-1 \\
0\end{array}$ & $\begin{array}{r}4 \\
2 \\
1 \\
53 \\
0 \\
5\end{array}$ & $\begin{array}{r}3 \\
1 \\
1 \\
2 \\
3 \\
1 \\
- \\
16 \\
118 \\
2 \\
1 \\
1 \\
32 \\
8 \\
1 \\
1 \\
3 \\
7 \\
7 \\
2 \\
- \\
5 \\
2 \\
1 \\
53 \\
1 \\
5\end{array}$ & $\begin{array}{l}1 \\
0 \\
0 \\
0 \\
0 \\
1 \\
0\end{array}$ & $\begin{array}{r}4 \\
3 \\
1 \\
2 \\
3 \\
1 \\
2 \\
11 \\
119 \\
4 \\
1 \\
29 \\
7\end{array}$ & $\begin{array}{r}4 \\
3 \\
1 \\
2 \\
3 \\
1 \\
2 \\
2 \\
17 \\
119 \\
4 \\
\\
1 \\
32 \\
8 \\
1 \\
1 \\
3 \\
8 \\
8 \\
2 \\
5 \\
1 \\
6 \\
6 \\
3 \\
1 \\
55 \\
1 \\
1 \\
5\end{array}$ \\
\hline Partial (ns) & 958 & 635 & $1.593(44)$ & 982 & 1.202 & $2.184(65)$ & 1.940 & 1.837 & $3.777(79)$ \\
\hline $\begin{array}{l}\text { Ae. (Och) } \\
\text { Serralus Group } \\
\text { Cx.(Cux) } \\
\text { Coronator Group } \\
\text { sp. } \\
\text { Cx.(Mcx) } \\
\text { Imitator Group } \\
\text { Pleristriatus Group } \\
\text { sp. } \\
\text { Cx.(Mel) } \\
\text { Atratus Group } \\
\text { Melanoconion Section } \\
\text { Pilosus Group } \\
\text { sp. } \\
\text { Ph. } \\
\text { palmata/diabolica (near) } \\
\text { sp. } \\
\text { Ps. (Jan) } \\
\text { albigenu/varipos } \\
\text { Wy. (Den) } \\
\text { airosaihowardi/luteoventralis } \\
\text { felicia/pampeites } \\
\text { mystes/finlayi }\end{array}$ & $\begin{array}{l}0 \\
0 \\
0 \\
0 \\
0\end{array}$ & $\begin{array}{l}- \\
- \\
5\end{array}$ & $\begin{array}{r}5 \\
42 \\
26 \\
11 \\
2 \\
1 \\
1 \\
1 \\
22 \\
2 \\
- \\
- \\
- \\
5 \\
2\end{array}$ & $\frac{0}{0}$ & $\begin{array}{r}466 \\
66 \\
95 \\
57 \\
120\end{array}$ & $\begin{array}{r}466 \\
66 \\
95 \\
57 \\
120 \\
4 \\
\overline{28} \\
- \\
5 \\
4 \\
1\end{array}$ & $\begin{array}{l}0 \\
0 \\
0 \\
0\end{array}$ & \begin{tabular}{r|}
471 \\
108 \\
121 \\
68 \\
2 \\
121 \\
5 \\
1 \\
50 \\
2 \\
5 \\
4 \\
1 \\
25 \\
5 \\
6
\end{tabular} & $\begin{array}{r}471 \\
108 \\
121 \\
68 \\
2 \\
121 \\
5 \\
1 \\
50 \\
2 \\
5 \\
4 \\
1 \\
25 \\
5 \\
6\end{array}$ \\
\hline Partial & 0 & 120 & 120 & 0 & 875 & 875 & 0 & 995 & 995 \\
\hline Total & 958 & 755 & 1.713 & 982 & 2.077 & 3.059 & 1.940 & 2.832 & 4.772 \\
\hline
\end{tabular}

(ns) - Number of species. 

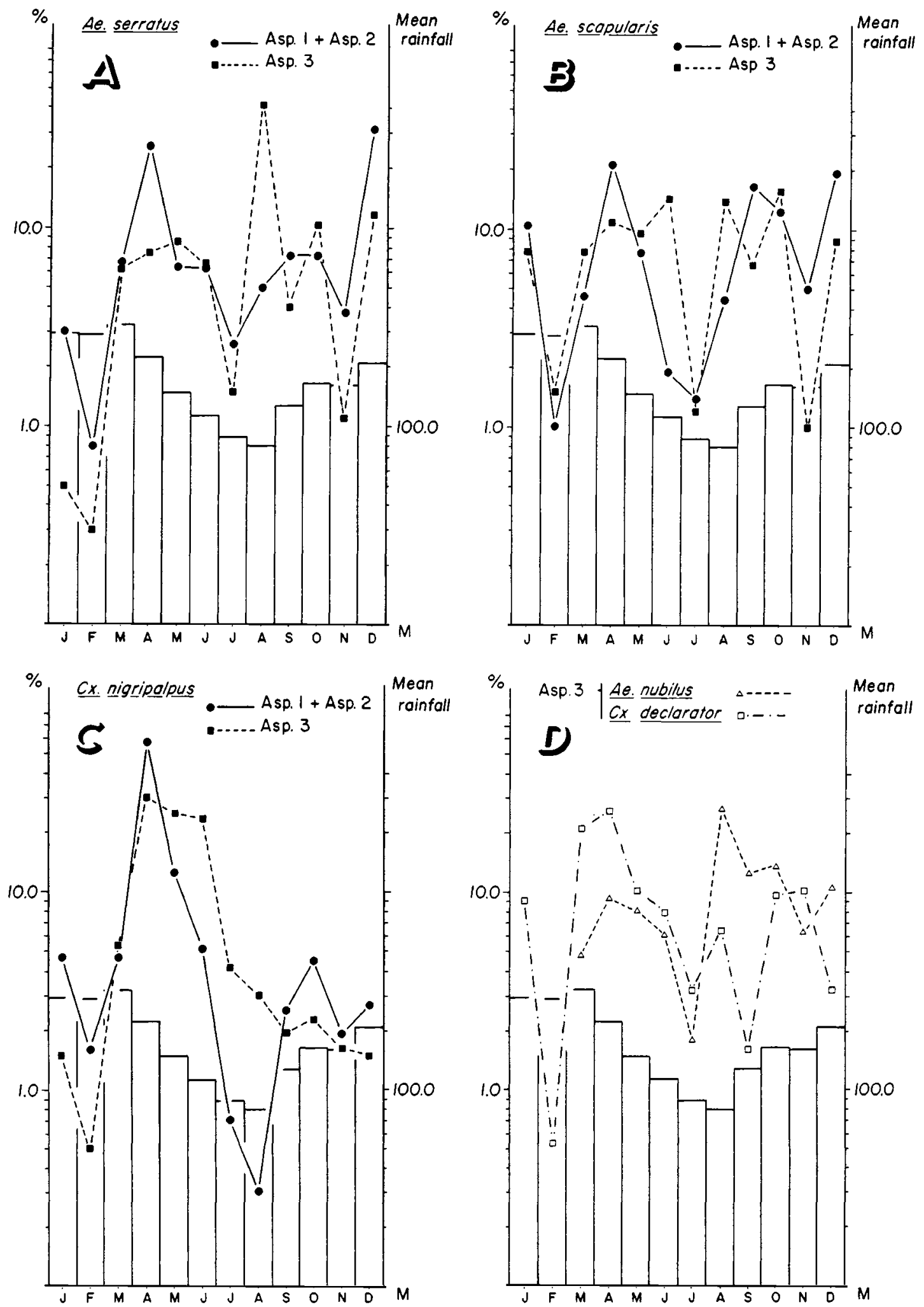

Figure 2. Monthly percontago rates distribution of resting adults caught in the ES residual woods (Asp.1 and Asp.2) and in the PQM secondary bush (Asp.3), from January 1992 through January 1993. Bars represent mean rainfall: A - Ae. sorratus; B - Ae. scapularis; C - Cx. nigripalpus; D - Ae. nubilus and Cx. declarator. 


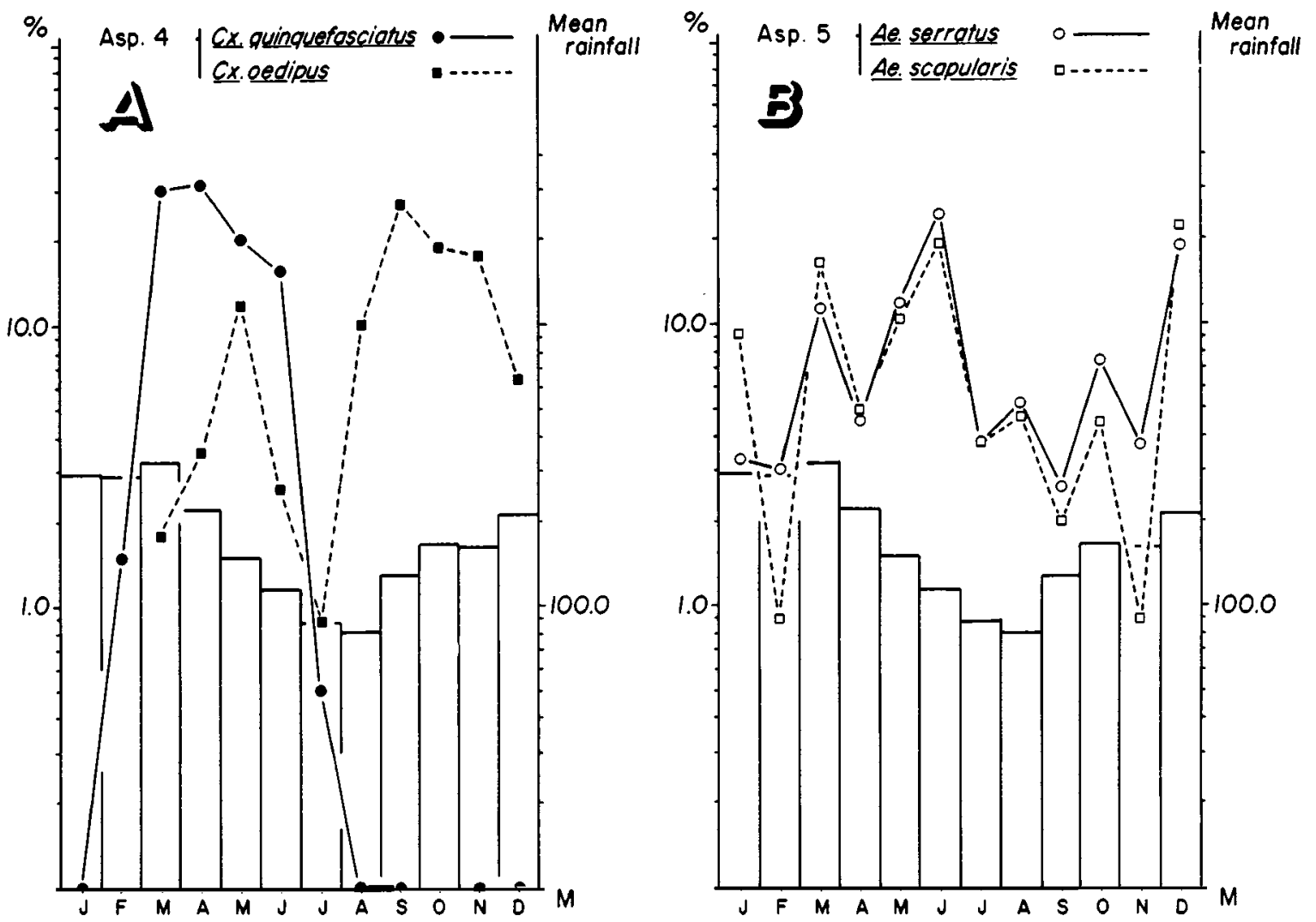

Figure 3. Monthly percontage rates distribution of resting adults caught in the FT region in a peridomestic onvironment (Asp.4) and at primitive forest (Asp.5), from January 1992 through January 1993. Bars reprosent mean rainfall means; A - Cx. quinquefasciatus and Cx. oedipus; $B$ - Ae. scapularis and Ae. serratus.

The monthly percentage distributions of $A e$. scapularis and Ae. serratus collections are presented in Figure 3B, and suggest a similar trend between them throughout the year.

Biodiversity - The overall biodiversity indices $(\alpha)$, with $95.0 \%$ confidence intervals of the number of resting mosquito species ( $n$ ) collected from many habitats, were $16.0 \pm 0.8$ for ES plus $P Q M$, and $14.0 \pm 0.7$ for FT. The comparison among the several sites (Tables 1 and 2) resulted in indices as follows :

Site

ES residual woods A (Asp.1)

B (Asp.2)

POM secondary bush

(Asp.3)

FT peridomestic

(Asp.4)

FT primitive forest

(Asp.5)

A quantilative difference was recorded between the residual woods and the secondary bush samples (Asp.1, Asp.2, Asp.3). Ilowever, analysing the data from woods $A$ and $B$, shows that the number of species was 82 , of which 29 were found only at A, 14 only at B and 39 were common to both sites. Thus, no quantitative difference was found when the total numbers of species collected were compared with those found in the secondary bush (Asp.3), where 83 species were recorded.

As for the FT region, of the total number of 79 species identified, 14 were found only in the peridomestic environment, 35 only in the primitive forest and 30 in both habitats. As cxpected, a quantitative difference was found among the peridomestic (Asp.4) and the primitive forest (Asp.5) environments. Figure 4 shows the main species percentages on the total number of resting mosquitocs collected at several siles.

Synanthropy - To cstimatc the degrees of synanthropy, a comparison among the specics collected in three different environments was made. Two of them resulted from anthropic activily as sctulements, and so were represented by the ES residual woods (Asp.1 + Asp.2), 

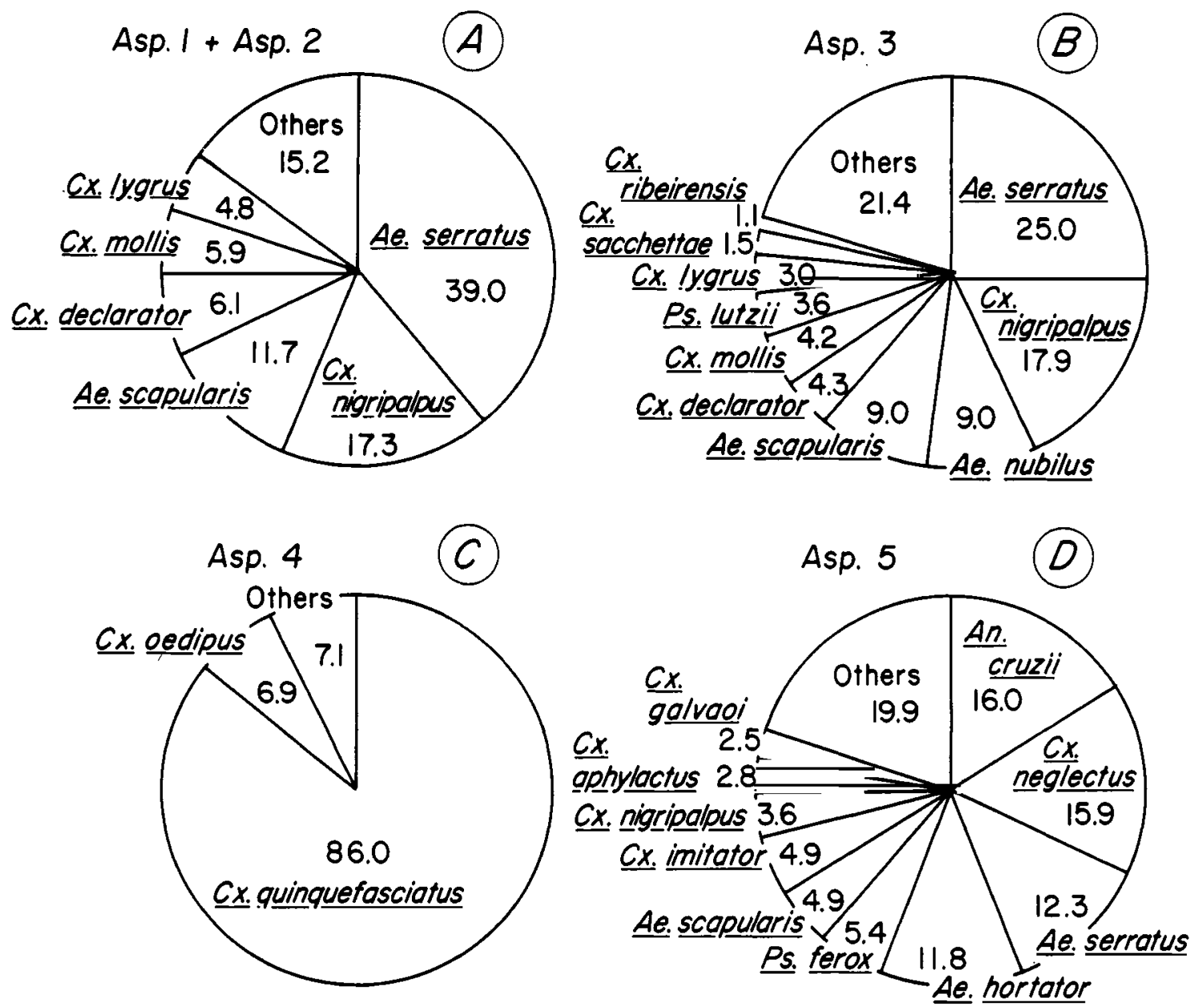

Figura 4. Diagrams of the distribution of main species as percentages of distribution on the total number of resting specimens collocted at the several sites; A - Residual woods (ES); B - Secondary bush (PQM); C - Peridomestic environment (FT); D - Primitive forest (FT).

jointly with the PQM sccondary bush (Asp.3) and the FT houselold surroundings (Asp.4). The third was represented by the wild environment of the FT primitive forest (Asp.5). The synanthropic indices (s) for the species collectcd in these three habitats are presented in Table 3. As can be seen some species showed a ligher degree of synanthropy than others, as regards their survival capacity and consequent adaptation to the artificial human environment. An explanation of the meaning of these indices is given in Figure 5.

The synanthropic ratios (sr) were estimated by comparing ES + PQM/FT data, and consequently the results of Asp. $1+$ Asp. $2+$ Asp. 3 wore divided by those of Asp.5. Taking into consideration those specics of which at least 100 specimens were collected, the resulting ratios were as follows:
Species

$\mathrm{sr}$

Aedes nubilus $\quad 202.5$

Culex ribeirensis $\quad 103.0$

Psorophora lutzii $\quad 86.0$

Cx. lygrus $\quad 62.0$

Cx. bidens $\quad 61.3$

Cx. sacchettae $\quad 61.0$

Limatus durhami $\quad 49.3$

Cx. declarator $\quad 38.2$

Cx. imitator $\quad 32.7$

Cx. nigripalpus $\quad 27.1$

Ae. serratus $\quad 17.0$

CX. mollis $\quad 15.5$

$\begin{array}{ll}\text { Cx. pedroi } & 13.7\end{array}$

Ae. scapularis $\quad 13.4$

Cx. coronator $\quad 12.0$

Cx. zeteki 3.1

Wy. confusa $\quad 1.2$

Ps. ferox 0.6

Cx. neglectus $\quad 0.2$

$\begin{array}{ll}\text { An. cruzii } & 0.02\end{array}$ 
Table 3. Synanthropy estimated as a percentage of Culicidae species sampled as resting adults. Indices were calculated by comparisons of the three main environments, according to Nuorteva's (1963) concepts*.

\begin{tabular}{lrrrr}
\hline Species & $\mathrm{a}(\%)$ & $\mathrm{b}(\%)$ & $\mathrm{c}(\%)$ & \multicolumn{1}{c}{$\mathrm{s}$} \\
\hline Ae. nubilus & 99.26 & 0.24 & 0.49 & +98.89 \\
Ae. scapularis & 92.28 & 0.83 & 6.87 & +85.82 \\
Ac. serratus & 94.41 & 0.02 & 5.58 & +88.84 \\
An. cruzii & 1.66 & 1.38 & 96.94 & 94.59 \\
Cx. bidens & 97.22 & 1.19 & 1.58 & +96.23 \\
Cx. imitator & 47.34 & 1.44 & 51.20 & 3.14 \\
Cx. mollis & 93.93 & 0.26 & 5.79 & +88.27 \\
Cx. neglectus & 13.30 & 1.23 & 85.46 & 71.54 \\
Cx. nigripalpus & 96.44 & 0.33 & 3.22 & +93.38 \\
Cx. pedroi & 91.79 & 1.49 & 6.71 & +85.82 \\
Cx. ribeirensis & 97.12 & 0.47 & 0.95 & +96.40 \\
Li. durhamii & 97.36 & 0.65 & 1.97 & +95.71 \\
Ps. ferox & 37.69 & 1.04 & 61.78 & 23.57 \\
Ps. lutzii & 97.72 & 1.13 & 1.13 & +97.72 \\
Wy. confusa & 52.5 & 1.66 & 45.8 & +7.53 \\
\hline
\end{tabular}

a Residual woods and secondary bush (Asp.1 + Asp.2 + Asp.3) at the anthropic settlement (ES).

b Peridomestic (Asp.4) environment (FT).

c Primitive forest (Asp.5) as wild environment (FT).

$s$ Synanthropic index $\left(s=\frac{2 a+b-2 c}{2}\right)$

With regards to the household environment represented by peridomestic collections (Asp.4), $C x$. quinquefasciatus was found only there. Bccause it was confined to that habitat, the synanthropy of this mosquito was clearly at the highest degrec. Although $C x$. oedipus was not found inside the FT forest environment (Asp.5), its synathropy ratio can neverthcless be estimated in the light of the FT peridomestic environment (Asp.4), just as the human domicile and the ES residual woods jointly with the PQM secondary bush (Asp.1 + Asp.2 + Asp.3) constitute the anthropic rural settlement. Thus $\mathrm{sr}=\mathrm{FT} / \mathrm{ES}+\mathrm{PQM}$ gave a ratio of 7.9 , indicating a degrce of synanthropy for that mosquito.

\section{Discussion}

The results reported here are concerned with regular sampling of mosquito resting sitcs. To a certain degrec, the results are a reflection of brecding places near which the adults, subsequent to resting after emergence, dispersed through the $\mathrm{cn}$ vironment. Therefore the data obtained may suggest the habitats where mosquitoes carry out their aclivitics.

Comparing these results with those previously reported (Forattini et al. ${ }^{10}, 1993$ ) it is remarkable that An. albitarsis was practically absent at the resting sitcs sampled in the two residual woods of the same Experimental Station (ES). On the other hand, Ae. scapularis was consistently collected at those sites, as well as at the irrigation system.

Significant monthly correlations with rainfall were found for Ae. nubilus $(\mathrm{r}=0.54 ; \mathrm{P}<0.05)$ and Ae. serratus $(\mathrm{r}=0.41 ; \mathrm{P}<0.05)$, both collected at PQM secondary bush, where they showed a peak associated with the dry season (August) (Figure 2 $A$ and D). Otherwise, the end of the rainy season (March to May) was significantly correlated to $C x$. declarator $(r=0.37 ; \mathrm{P}<0.05)$ collections in the same $\mathrm{PQM}$ environment (Figure 2D). Nevertheless, these relations varied according to the habitats and no correlations with rainfall were found in the monthly distribution of these species in the ES residual woods (Asp.1 + Asp.2) and in the FT primitive forest (Asp.5). In addition, Ae. scapularis and $C x$. nigripalpus showed no significant correlations with their monthly collections through the year. In the FT peridomestic environment, significance was found for $C x$. quinquefasciatus $(\mathrm{r}=0.32 ; \mathrm{P}<0.05)$ and for $C x$. oedipus $(\mathrm{r}=0.46 ; \mathrm{P}<0.05)$, correlated to the wet season (Figure $3 \mathrm{~A}$ ). These results agree with those previously reported (Forattini et al. $1993^{9}, 1993^{10}$ ) which show Ae. scapularis as a mosquito occurring throughout the year, both in the anthropic and the primitive environments (Figures 2B, 3B). As for Culcx species, adults were collected in larger numbers when the rainy senson was finishing or starting. This is probably associaled with the greater abundance of larval habitats, which tend to be flushed out during heavy summer rains.

The ES plus PQM data indicaled higher biodiversity than that observed in the FT primitive environment. The explanation may be found in the influence of vegetation that, even in the human settlements, harbours mosquito specics favouring blood sources from cattle and other domesticated animals (Figure 1B), Obviously mosquito specics diversity was lower in the household environment, where $C x$. quinquefasciatus is the dominant species.

It secms evident that a mosquito species group which includes Ae. nubilus, Ae. scapularis, Ae. serratus, $C x$. nigripalpus, $C x$. ribeirensis and othcrs (Figure 5) is favored by the installation of human sculcments. Natural environmental alterations result in a patchy remnant vegctation that provides resting places for many mosquito species. Inadiction, domestic livestock furnish blood sources. Thus, such mosquito species may find resources good cnough to cnable them to survive and their population to increase. According to the Povolny ${ }^{19}$ (1971) classification, these species may be considered as hemisynanthropes with respect to their synanthropic indices (s) and ratios (sr) (Tablc 3; Figure 5). The present results support previous observations on Ae. scapularis and Culex species, 


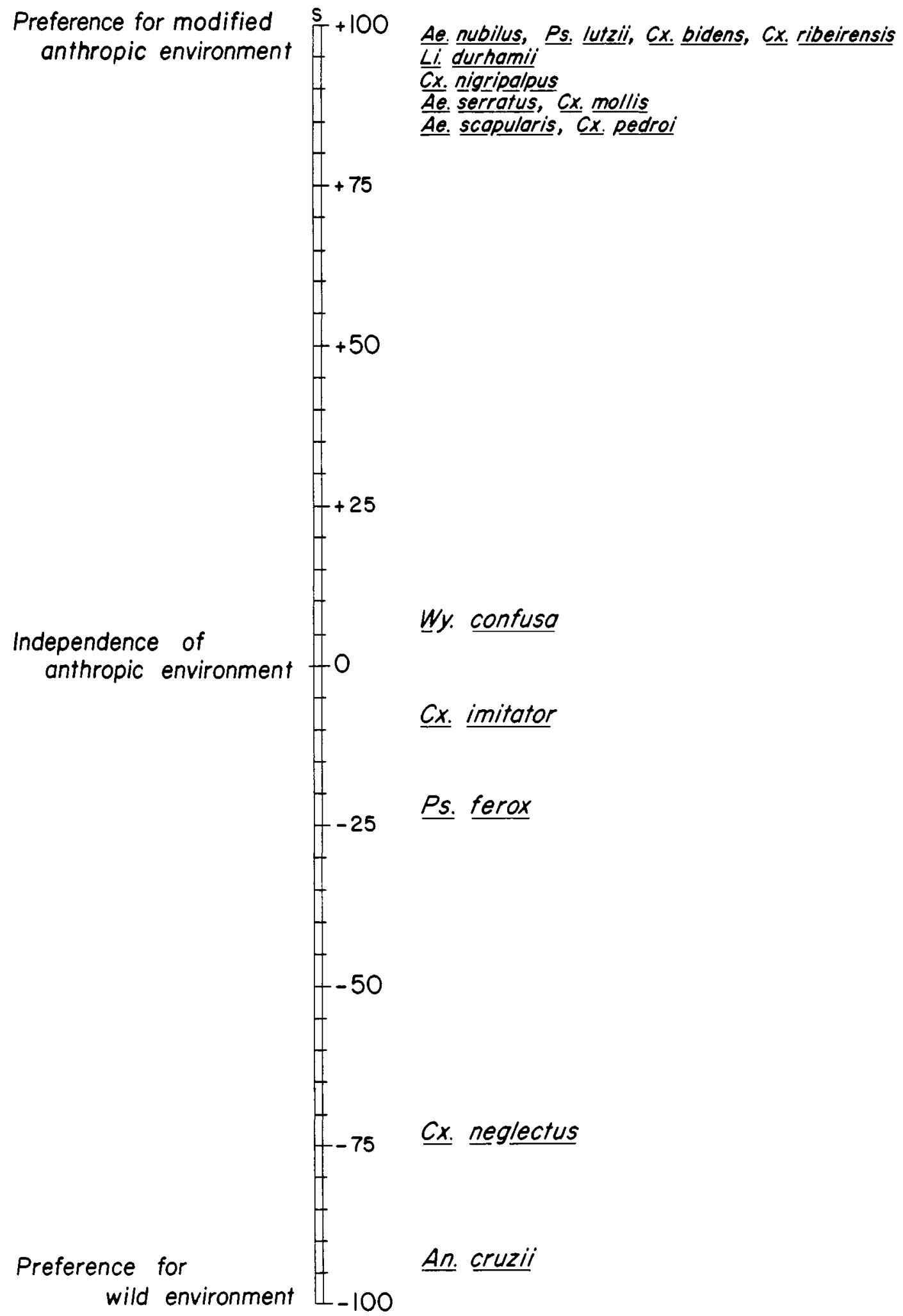

Figure 5. Representation of different degrees of Culicidae synathropic indices (s) as between three habitats, according to the level of anthropic modification of the natural environmont. 
such as $C x$. ribeirensis and others (Forattini ct al. 4,6,7, 1987, 1990, 1991; Gomes et al. ${ }^{11}$ 1990). At the opposite extreme An. cruzii may be classified as an asynanthrope mosquito which decreases significantly in accordance with the development of the anthropic alterations to the natural environment. Even when visiting households regularly seeking blood adult females do not remain there, but instead fly after feeding to their natural habitats (Forattini et al ${ }^{6,8} 1990,1993$ ).

As for the peridomestic environment, $C x$. quinquefasciatus must obviously be considered as an endophilous eusynathropic mosquito. The results obtained here strongly suggest that $C x$. oedipus may be a local species developing exophilous eusynanthropic behaviour. That is, it may be associated with the manmade environment but without necessarily requiring human habitation. In any case, it is a species deserving further attention.

In conclusion, from the data obtained through these studies it seems pertinent to consider that, from the epidemiological point of view, scveral species of outdoor mosquito can to develop bchavior that brings them into an association with the rural anthropic environment. Furthermore, all the evidence suggests that they may find resources available there for their survival there and population increase. Such aspects as thesc may have implications for the transmission of infectious discases, from the foci located in the natural environment to man and livestock.

FORATTINI, O.P. et al. Estudos sobre mosquitos (Diptcra: Culicidae) e ambiente antrópico. 4 - Coleta de adultos $\mathrm{em}$ abrigos e níveis de sinantropia, na região sudeste do Brasil. Rev. Saúde Pública, 27: 398-411, 1993. Relata-se os resultados obtidos com a coleta regular de Culicidac adultos $\mathrm{cm}$ diversos abrigos natur ais e peridomiciliares no período de janeiro de 1992 a janeiro de 1993, em locais do Vale do Ribeira. Mediante os aspectos de biodiversidade, pôde-se obscrvar que, a vegctação remancscente situada no ambiente rural, favorece a sobrevivência $e$ o aumento populacional de algumas espécics. Dentre elas, menciona-se Ae. scapularis, Ae. serralus, representantes de $C x$. (Culex) como $C x$. nigripalpus $\mathrm{e}$ de $C x$. (Melanoconion) como Cx. ribcirensis. Esse papel pode-se possivelmente atribuir à criação de animais domésticos nesses locais, o que resulta $\mathrm{cm}$ maior númcro de fontes sanguíneas. As espécies foram classificadas como hemisinantrópicas, sendo $C x$. oedipus mosquito aparentemente cvoluindo para hábitos eusinantrópicos. Por sua vez, An. cruzii revelouse assinantrópico, uma vez que mostrou baixo nível de comparecimento nas coletas efetuadas no ambiente modificado pelo homem. Menciona-se a possibilidade de implicações epidemiológicas na transmissão de agentes infecciosos dotados de focos extradomiciliares.

Descritores: Mosquitos. Ecologia de vetores.

\section{References}

1. BREELAND, S. Studies on the diuma resting habits of Anopheles pseudopunctipennis and Anopheles albima. nus in El Salvador. Mosq. News, 32:99-106, 1972.

2. BREELAND, S. Studies on the ecology of Anopheles albimanus. Am. J. Trop. Med. Hyg., 21:751-4, 1972.

3. FISHER, R.A.; CORBET, A.S.; WILLIAMS, C.D. The relation between the number of species and the number of individuals in a random sample for an animal population. J. Anim. Ecol., 12:42-58, 1943.

4. FORATTLNI, O.P.; GOMES, A.de C.; NATAL, D.; KAKITANI, I.; MARUCCI, D. Freqüência domiciliar e endofilia de mosquitos Culicidae no Vale do Ribeira, São Paulo, Brasil. Rev. Saúde Pública, 21: 188-92, 1987.

5. FORATTINI, O.P.; GOMES, A.de C.; NATAL, D.; KAKITANI, I.; MARUCCI, D. Preferências alimentares cm mosquitos Culicidae no Vale do Ribeira, São Paulo, Brasil. Rev. Saúde Pública, 21:171-87, 1987.

6. FORATTINI, O.P.; GOMES, A.de C.; SANTOS, J.L.F.dos; KAKITANI, I.; MARUCCI, D. Freqüência ao ambiente humano e dispersão de mosquitos Culicidae em árca adjacente à mata alântica primitiva da planícic. Rev. Saúde Pública, 24:101-7, 1990.

7. FORATTINI, O.P.; GOMES, A. de C.; KAKITANI, I.; MARUCCI, D. Observaçôes sobre domiciliação de mosquito Culex (Melanoconion) em ambiente com acentuadas modificaçōes antrópicas. Rev. Saúde Pública, 25:257-66, 1991.

8. FORATTLNI, O.P.; KAKITA.VI, I.; MASSAD, E.; GOMES, A. de C. Studies on mosquitoes (Diptera: Culicidac) and anthropic environment. 1- Parity of blood secking Anopheles (Kerteszia) in SoulhEastem Brazil. Rev. Saúde Pública, 27:1-8, 1993.

9. FORATTINI, O.P.; KAKITANI, I:; MASSAD, E.; MARUCCI, D. Studies on mosquitoes (Diptera: Culicidae) and anthropic environment. 2- Immature stages rescarch at the rice irrigation system location in South-Eastem, Brazil. Rev. Saúde Pública, 27: $227-$ 36, 1993

10. FORATIINI, O.P.; KAKITANT, I.; MASSAD, E.; MARUCCI, D. Studies on mosquitoes (Diptera: Culicidac) and anthropic environment. 3. Survey of adult stages at the rice irrigation system and the emergence of Anopheles albitarsis in SouthEastem, Brazil. Rev. Salude Pública, 27: 313-25,1993.

11. GOMES, A.de C. \& FOR $\triangle T T N T$, O.P. Abrigos de mosquitos Culex (Culex) em zona rural (Diptera: Culicidac). Rev. Saúde Pública, 24:394-7, 1990.

12. INSTITUTO OCEANOGR ÁFCO (USP). Bol. climatol, Inst. Oceanogr., São Paulo, (o): 1-6, 1989.

13. IRBY, W.S. \& APPERSON, C.S. Spatial and temporal distribution of resting female mosquitoes (Diptera: Culicidac) in the costal plain of North Carolina. J. Med. Entomol., 29:150-9, 1992.

14. NASCI, R.S. A lightweight batterypowered aspirator for collecting resting mosquitoes in the ficld. Mosq. News, 41:808-11, 1981.

15. NATAL, D.: PAGANELLI, C.H.; SANTOS, J.L.F.dos Composição da população adulta de Culex (Culex) quinquefasciatus Say, $1823 \mathrm{~cm}$ ecótopos próximos à represa Edgar de Souza, no Município de Santana de Pamaîba, Estado de São Paulo, Brasil. Rev. Bras. Ento. mol., 35:539-43, 1991.

16. NAVARRO, O., A.; MARQUETTI, F.M del C.; BISSET, L., J.A.; GARCIA, F.A. Estudio estacional de sitios de reposo de anofelinos (Diptera: Culicidae); informe preliminar. Rev. Cubana Med. Trop., 38:21-6, 1986. 
17. NAVARRO, O., A.; OLANGE, J.; MARQUETTI, F.M. dd C.; BISSET, L.J.A.; GARCIA, F.A. Esudio de los sitios de reposo poshematofagicos extradomiciliarios de Anopheles (A.) crucians Wiedemann, 1828 (Diptera: Culicidae). Rev. Cubana Med. Trop., 39:3343, 1987.

18. NUORTEVA, P. Synanthropy of blowflies (Diph, Calliphoridae) in Finland. Ann. Entomol. Fenn., 29:1-49, 1963.

19. POVOLNY, D. Synanthropy. In: Greenberg, B., ed. Flies and disease. Princeton, Princeton Univ. Press, 1971. v.1, p.16-54.

20. REINERT, J.F. Mosquito generic and subgeneric abbreviations (Diptera: Culicidae). Mosq. Syst., 7:105-10, 1975.

21. REINERT, J.F. Abbreviations for mosquito generic and subgeneric taxa established since 1975 (Diptera: Culicidae). Mosq. Syst., 14:124-6, 1982.
22. REISEN, W.K.; HAYES, C.G.; AZRA, Ki NLAZ, S.; MAIIMOOD, F.; PARVEEN, T.; BOREHAM, P.F.L. West Nile vinus in Pakistan. II. Entomological studies at Changa Manga National Forest, Punjab Province. Trans. R. Soc. Trop. Med. Hyg., 76:437-48, 1982.

23. RUBIOPALIS, Y. \& CURTIS, C.F. Biting and resting behaviour of anophelines in westem Venezuela and implications for control of malaria transmission. Med. Vet. Entomol., 6:325-34, 1992.

24. SERVICE, M.W. A critical review of procedures for sampling populations of adult mosquitoes. Bull. Entomol. Res., 67:343-82, 1977.

25. SERVICE, M.W. Mosquito ecology: field sampling methods. 2nd ed. London, Elsevier, 1993.

Recebido para publicaçäo 5.10 .93 Aprovado para publicação 16.10 .93 